\title{
13 AFRICAN TRADITIONAL RELIGION IN POST- COLONIAL ZIMBABWE: A SUSTAINABLE HERITAGE FOR WATER RESOURCES MANAGEMENT
}

\section{Bernard P. Humbe ${ }^{1}$}

\section{INTRODUCTION}

This chapter explores sustainable heritage in the management of water sources by rural communities of Zimbabwe. The problem it addresses focuses on heritage for water resources management in rustic communities. The coming of Christianity as a modern way of worship despised African traditional religious strategies of water resource conservation and management. This was compounded by the introduction of water laws, by both colonial and postcolonial governments that deprived indigenous people of their rights to water management systems. In addition, it must be recognised that many changes have occurred as a result of non-African influential forces that have accompanied globalisation. Bearing in mind that the Zimbabwean rural economy is agricultural in nature, lack of a sustainable heritage for water resources management has retarded socio-economic development in rural areas given the importance of water to agriculture.

It is against the above that this chapter argues for the increased harnessing of indigenous religion by governments and non-governmental organisations (NGOs) toward management of water systems in rural communities. Indigenous religion shall be used interchangeably with African traditional religion (ATR), Shona religion and Mwari religion. It is from their indigenous religious worldview that these communities derive so-called indigenous or traditional knowledge from which laws are extracted to manage water bodies. For the indigenous, water heritage is a cumulative set of knowledge, practices, understandings and interpretations concerning themselves and their environment, passed from generation to generation. Their constant interaction with the environment facilitates development of knowledge about water systems which is preserved in their cultural ambiance.

The inquiry in this chapter is premised on qualitative and descriptive case studies of Buhera and water sources management through integration of African indigenous religion. Field work was conducted over the course of six months, extending from 10 August 2015 to 15 February 2016. Complemented by considerations of phenomenology of religion, the study allowed for a systematic collection of data by investigating the cultural realities of people in the face of water crisis, taking into account that African indigenous religion is

1 Department of Philosophy and Religious Studies, Great Zimbabwe University. 
an important aspect of the Shona people's way of life..$^{2}$ The sampled population included people from the Shona linguistic groups located in Buhera District. Interview responses enabled an understanding of the dynamics of variables ${ }^{3}$ within the Buhera District that influence management of water bodies. Through observation, the question of how African indigenous religion is used in water management systems in Shona rural communities was answered with reference to the population's religious worldview.

\section{A cartography of the Shona people}

The Shona is a large ethnic group in Zimbabwe. The term Shona was officially ascribed to this group of the indigenous people by the white South African linguist, Clement M Doke in 1929. Doke identified people whose dialects had mutual intelligibility. As a result, the term Shona was meant to embrace five major dialects: Karanga, Zezuru, Ndau, Manyika and Korekore. ${ }^{4}$ Michael FC Bourdillon, a sociologist of religion, acknowledges diversity among these groups. He discovered that the term, Shona, while primarily a linguistic classification, is also a convenient term to designate a particular group of people who not only share language, but also have shared religious, cultural and, to some extent, historical links and experiences. ${ }^{5}$

Buhera, one of Manicaland Province's seven districts, is home to 24,072 habitants. ${ }^{6}$ The region under study falls within Agro-ecological zone, region 5 with an average annual rainfall of less than 200 millimetre per year. The average temperature for the district annually is 34 degrees celsius. ${ }^{7}$ Therefore, Buhera is a hot and dry district. Within the district, special focus is paid on Nyashanu and Chamutsa chieftaincies. The two chiefs preside over communities of indigenous people who migrated from various neighbouring districts, which include Chipinge, Bocha, Chivhu, Gutu and Bikita. It is common to hear the following dialects in the area: Ndau, Zezuru, Karanga and Manyika. The multiplicity of dialects points to the diversity of cultures within these different ethnic groups. However, because these people stay in the same vicinity, there is fusion of traditional cultural practices and even language is shared, such that sometimes

2 Masaka D and Makahamadze T. 2013. "The Proverb: A Preserver of Shona Traditional Religion and Ethical Code", The Journal of Pan African Studies 6(5): 132-143.

3 Maposa RS and Mhaka E. 2013. “Indigenous Culture and Water Technology: A reflection on the Significance of the Shona Culture in light of climate change in Zimbabwe", Greener Journal of Art and Humanities 3(2):024-029.

4 Maposa RS and Humbe BP. 2012. Indigenous Religion and HIV and AIDS Management in Zimbabwe: An African Perspective, LAP Lambert Academic.

5 Bourdillion MFC. 1976. The Shona People, Gweru: Mambo.

6 Buhera District. Online at: www.geoview.info

7 Chinamasa E and Mavhiza FM. 2014. "Participatory Water Sources management model for schools: Case of Buhera district, Zimbabwe", Journal of Humanities and Social Science 19(4):21-32. 
it is difficult for an outsider to separate the fine thread which ties these Shona people together.

The above pluralism has both positive and negative bearing on the indigenous people's aquatic cultures, as well. With continued population growth and socioeconomic development, water demands in Buhera district are rising. Modern legislation has alienated indigenous Shona people from their heritage of water resources management. This creates a problem, since in their cultural locale, the Shona perceive water as a religious phenomenon, which should be owned and managed by the users. Breakdown of boreholes and drying-up of both surface and underground water bodies results in the villagers' water rights being severely violated. Therefore, in the water policy of Zimbabwe, there is an urgent need for a legal pluralistic framework which should be used to govern water practices in rural areas.

\section{Traditional religious and legal landscape of the Shona people and their water resources}

The Shonas' indigenous religion influences their thoughts, feelings, interests, aspirations and actions, as posited by John S Mbiti, author on African traditional religion, when he advanced the now classic expression that Africans are "notoriously religious". ${ }^{8}$ The Shona believe in a Supreme Being called Mwari. ${ }^{9}$ Because of their strong belief in Mwari, Shona religiosity is widely understood as Mwari religion. ${ }^{10}$ Mazambara calls it Mwariology. ${ }^{11}$ Mwari is the creator of the universe and is the one who sustains it. He is approached via mediation by through the vadzimu (ancestral spirits), who are believed to possess supernatural powers. These ancestral spirits are regarded to be the central to Shona humanity and wellbeing in Zimbabwe. ${ }^{12}$ The spirits can bring fortunes or misfortunes to their progenitors, depending on how the living relatives appease them. Shona also believe in guardian spirits, called mhondoro, and various wandering alien spirits known as mashavi. All these spiritual entities are sources of good or bad aptitudes.

Preoccupation of belief in supernatural forces directs and influences the Shona people's course of life. This idea is further buttressed by Kwame Gyekye, an African philosopher, who argues that even though some Shona people are aware of the purely scientific causal explanations, they do not often consider these as profound enough to offer complete satisfaction in accounting for the

8 Mbiti JS. 1969. African Religions and Philosophy. New York: Doubleday, 4.

9 Muzorehwa GH. 2014. African origins of monotheism: challenging the Eurocentric interpretation of God concepts on the continent and in diaspora. Eugene: Pickwick.

10 Mukonyora I. 1999. "Women and Ecology in Shona Religion", Word and World XIX(3):276-284.

11 Interview with P Mazambara, 11 August 2016. Mazambara is a lecturer of Zimbabwean culture at Great Zimbabwe University.

12 See Maposa and Humbe, Indigenous Religion. 
events of life that they feel need explanation. ${ }^{13}$ Rather, they resort to indigenous religion that fully address the "why" and "how" questions with regard to the status of a given water source. Therefore, everything and every act are looked at from a religious perspective.

Shona religion has traditional sacred practitioners (traditional healer, spirit medium, village head, headman and chief), who through use of religious laws act as gatekeepers to sacred reality of water bodies in indigenous communities. Within the context of an indigenous African society, ATR heritage is expressed via a people's beliefs, practices, ceremonies, rituals, festivals, symbols, objects, sacred places, morals, religious leaders and the revered practitioners, ${ }^{14}$ but this is not necessarily reflected in Zimbabwe water policies.

Given the above scenario, the Shona give water a religious meaning. Water belongs to the living, the unborn as well as to the dead. In fact, of all the many non-living substances and items in Africa, there is probably no other which shares such rich water symbolism. The overwhelming importance of water lies in its connection with life. ${ }^{15}$ Shona pay allegiance to its sacredness when they use it directly or indirectly in performance of their various ritualistic activities that enhance their well-being.

When it comes to the management of water and other resources, the hierarchy of the Shona polity consists of the Sabhuku (village head), the Sadunhu (headman) and the Ishe (chief). ${ }^{16}$ Usually, legal proceedings start at the village level. The chief's court is the final court of appeal before entering the state system of district courts presided by professional judicial officers. However, the authority implied by the Traditional Leaders Act of 2013, ensures that the courts of chiefs and headmen have a more positive role in the legal and social frame work of the lives of rural people.

Shona customary law has a number of distinctive characteristics: It is unwritten; customary laws are directly validated by community acceptance; customary laws are not clearly defined and can vary from district to district. Like many groups in Africa, the Shona understand their laws by virtue of being and living as Africans. Customary courts are open to all and there are no restrictions regarding evidence. Shona law also makes little distinction between criminal and civil law and all litigation is aimed at reconciliation.

Customary laws have existed in parallel with statutory water legislation for many years in Zimbabwe. Rights to water resources under customary law

13 Gyekye in Chingombe et al. 1997. Online at: http://aessweb.com/journal-detail. php?id=5012

14 Mbiti, African Religions and Philosophy, 4.

15 Kriel A. 1989. Roots of African Thought 2 Sources of Power, Pretoria: University of Pretoria, 3.

16 The Shona religio-political system is organised hierarchically, starting with the village head, followed by headman and at its apex is the chief. They are all custodians of the indigenous people's cultural heritage. 
are conceptualised in a fundamentally different way from the requirements of statutory law. This has implications for the resource use and management model to be implemented. According to customary law and practice, water is treated as a God-given resource that all are entitled to use. By stating that water belongs to God, people are saying it belongs to the land. And, by saying it belongs to the land, they are saying it belongs to them. Therefore, the control and management of water should be in their hands. They see water as a basic human right because it is a source of survival: water is life. ${ }^{17}$

Because these indigenous customary law practices are established over the years, they are critical considerations that need to be reflected in the law for the better management and voluntary enforcement of the laws. In the Shona religious cosmos, the environment includes an interweaving of the spiritual world, humanity and nature. These three are bonded and interdependent. Therefore, the Shona understand themselves as part of the environment. The spiritual world is manifested in the landscape through phenomena such as water bodies. ${ }^{18}$ There is no doubt that, as they utilise the water sources overtly and covertly, the people are determined to protect water sources as the abodes of their spiritual beings.

\section{Government of Zimbabwe water policy}

Against this backdrop of religious ritual and customary law, the government of Zimbabwe embarked on a reform of the water sector in 1995. This came as a result of the inadequacy of the 1976 Water Act, a revision of the original Water Act of $1927 .{ }^{19}$ As will be shown below, the policy on water resources, as highlighted by the Water Act and the Zimbabwe National Water Authority Act (ZINWA), ${ }^{20}$ resulted into improved management and use of the country's water resources.

The two water acts provided that:

- All surface and underground water will belong to the state.

- All Zimbabweans must have access to water for primary use.

- All water must be beneficially used.

- Water should be treated as an economic good.

- Water tariffs will need to take cognisance of those unable to pay the full price.

17 Latham in Chikozho C and Latham J. 2005. "Shona customary practices in the context of water sector reforms in Zimbabwe." International Workshop on African Water Laws: Plural Legislative Frameworks for Rural Water Management in Africa. Johannesburg, South Africa, January 26-28.

18 Fontein in Maposa and Mhaka, "Indigenous Culture and Water Technology".

19 Chikozho and Latham, "Shona customary practices", 2.

20 It is a wholly government-owned arm that manages water systems. The Authority was formed in 2000 following the promulgation of ZINWA and its functions and mandate are drawn from the same act and the Water Act of 1998. 


\section{Heritage of Land, Water and Great Zimbabwe}

- Water rights in perpetuity need to be replaced by water permits issued for a specific time period.

- Water management should involve all stakeholders at lowest possible level and

- The environment is to be considered as a consumer in its own right. ${ }^{21}$

Alterations to the water reforms continued and, in December 2012, the National Water Policy was approved by government and publicly launched on 22 March 2013. The policy envisages that, within five years, ZINWA will focus on its core functions of planning, developing and managing the country's water resources in accordance with the provisions of the Water Act of $1998 .^{22}$ It reallocates responsibility for water and sanitation services to local governments, both urban and rural. Institutional accountability for rural Water, Sanitation and Hygiene (WASH) will resort under Rural District Councils (RDCs), with the central government providing leadership and oversight. ${ }^{23}$

A close look at the above water policy shows that though there is recognition of traditional leadership in water developmental projects, there is no provision for traditional law and practice as such in the act - except perhaps in the recognition of primary rights to water. Therefore, the postcolonial water policy in Zimbabwe is divesting the indigenous people of their water rights. The latter rights start from ownership of the water sources as per indigenous religious culture, for example the case of boreholes. There is need to also understand boreholes in the context of indigenous religion. They are symbolic in that they connect the underground world with the human world by supplying water that is vital for sustenance of both human and non-human life. The water comes from the underground world where ancestors are buried. The functionality or boreholes is propelled by the spirits of the land.

This has been ignored and maligned by the government, rural district councils and non-governmental organisations. ${ }^{24}$ Public opinion has been taken into account in the formulation of these government water laws. However, policymakers and legislators operate from cities, hence they are not well acquainted with traditional laws that, though not codified in written form, have been in existence since time immemorial, are based on long-standing practice, and are essential in rural water governance issues.

\section{CASE STUDIES IN RELIGION AND WATER SOURCES IN ZIMBABWE}

Buhera's several water sources are socially and religiously constructed. They vary from natural sources such as rivers, streams, pools and rainwater, to human

21 Ibid.

22 The Zimbabwe Water Forum Policy Note 3.0, April 2013, 3.

23 Ibid.

24 Rusinga O and Maposa RS. 2010. “Traditional Religion and natural resources: A reflection on the significance of indigenous knowledge systems on the utilisation of natural resources among the Ndau People in south-eastern Zimbabwe", Journal of Ecology and the Natural Environment 2(9):201-206. 
made sources such as wells, boreholes and dams. By force of circumstance, communities depend on several sources for water supply, for no single source is capable of supplying all the water needs throughout the year. The majority of the villagers in the region acknowledge that boreholes and hand-dug wells are the major sources of water in their communities. Boreholes constitute $52.3 \%$ of the sources, while hand dug deep wells constitute $22.6 \%$. Thus, about $80 \%$ of Buhera's water is groundwater. ${ }^{25}$

\section{Case 1: Boreholes and religious ritual}

According to the Rural District Council Act 29:17, it is the prerogative of the Ward Development Committee (WADCO) to meet the water needs, via, for example, requests for additional water points and assistance in the maintenance of existing ones. The so-called District Development Fund (DDF) accounts for $55 \%$ of the boreholes in the district ${ }^{26}$ and any NGO that sinks a borehole is required to hand it over to the DDF. The latter is then is responsible for the management of the borehole as is the case with all boreholes in the district. In Buhera, $40 \%$ of the boreholes have been drilled with the assistance of the NGOs which include: Africare, World Vision, Christian Care, Zimbabwe Red Cross and Mercy Corps. ${ }^{27}$

In Ward 27, the majority of the boreholes that function throughout the year are the ones that were sunk during the colonial regime, and they are known as migodhi yechikare (traditional boreholes). The following are the names of boreholes from which communities obtain water throughout the year: Mugodhi wekwaMakarara, Muzerengwa, Dakacha, Mugodo and Siyesiye. Traditional leaders were involved in identifying the sites where these boreholes were sunk. The sinking of the boreholes were preceded by the performance of rituals for the success of the drilling and the sustenance that the boreholes would provide. These boreholes are named after the villages in which they were sunk. Kutumidza zita (apt naming) constitutes one of the most important indigenous rituals in Africa. In fact, it is a vital rite de passage in several indigenous Shona communities in Zimbabwe, as well. ${ }^{28}$ The idea behind the naming ritual is that the water is transformed and assumes life embodied in the name. If a borehole is named after a person, the water source becomes incorporated into the family and community of that person. This increases people's sense of ownership of the borehole and translates in turn into maximum care of the water point. ${ }^{29}$

The families who look after these boreholes have implemented various strategies to prolong the lifespan of these boreholes. The water points are, for example, encircled using mupane logs. A mhanda (V-shape log) is inserted

25 See Chinamasa and Mavhiza, "Participatory Water Sources."

26 Ibid.

27 Ibid.

28 See Maposa and Humbe, Indigenous Religion.

29 Chambers in Chinamasa and Mavhiza, "Participatory Water Sources". 
underneath the hand pipe to prevent water users from smashing it against the ground. People take turns in fetching water in the spirit of community sharing, so mbawo (egocentrism) is discouraged. Indigenous communities also have expectations that regulate behaviour of water users at the water points. For example, if anyone has to bring a metal container, it must not contain any soot residue; bathing and laundry should not be done within the radius of hundred meters; the washing of nappies are strictly prohibited. In all, generally high standards of hygiene are to be maintained.

It is told that, in the late 1970s, after a quarrel with her husband, a woman in Nehumambi area defecated at one of the water points and the water dried up instantly. The reason given is that the community and its spirits were angered by such behaviour. Apparently the woman also lost her sanity and traditional healers confirmed that it was due to punishment from the ancestors. In functional terms, this incident served as a deterrent to other would-be transgressors of the customs that prevent the pollution of water sources. This is also a practical example in which the Shona managed their water resources. They are highly conscious of power enshrined in the traditional customs of the people as a collective group and as a cultural unit.

It is well acknowledged in communities that the traditional boreholes are strongly associated with mystical forces. The power of African religious laws rests wholly on the ascription of psychic powers to the water sources as the abodes of ancestral spirits. ${ }^{30}$ Unfortunately, as noted by Lekan Oyebande, the priority accorded to indigenous knowledge with regard to water management during the colonial era had not been sustained by post-independence governments of the country. ${ }^{31}$ Water has been aligned more to politics than religion.

In 2000, surveys of underground water by a Non-Governmental Organisation in conjunction with traditional leadership were carried out in Shiri area. However, politicians by-passed traditional chiefs in the actual borehole sinking project, by simply instructing drillers to sink the borehole near their homesteads. The boreholes hardly supplied communities with any water and this affected social development in Buhera. Though standards of living are difficult to measure, indicators of social development can be seen in the communities with access to enough water. Unavailability of water means that villagers spend the greater part of their time searching for water, negating other important chores and aspects of their social life. In other words, the availability of water is linked with the improvement of the well-being of villagers so that they can reach their full

30 Eneji CVO et al. 2012. "Traditional African Religion in Natural Conservation and Management in Cross River State, Nigeria", Environment and Natural Resource Research 2(4):45.

31 Oyebande in Gbadegesin N and Olorunfemi F. 2007. "Assessment of Rural Water Supply Management in Selected Rural Areas of State, Nigeria", ATPS Working Paper Series 49:2. 
potential. In securing the availability of water, traditional African religion itself becomes a resource toward development.

The above shows that integrating traditional knowledge into modern water resources management practices is crucial. The sinking of boreholes must respect the traditional beliefs of the Shona. Through their cultural heritage, indigenous people are versed with the kind of rituals to be performed before commencement of borehole sinking. In Ward 29, there is an area called Zomba, where several Shona freedom fighters were killed during the Zimbabwean liberation struggle. It is very difficult to start a successful water project in this area without performing proper rituals which appease the spirits of dead liberation fighters. Experiences of villagers show that in situations where traditional religion was overlooked, mysterious loss of equipment and injuries to machine operators occurred. Even for the one borehole which is functional, villagers, through their traditional leaders always communicate with the spiritual world to enhance borehole's sustainability. If spirits of the dead fighters are angered, it is said, they are seen hovering around the water point especially at night. So, the success of any water management strategy rests on the involvement of the traditional belief systems of the beneficiaries of the water point. ${ }^{32}$

\section{Case 2: Hand-dug deep wells and indigenous "water knowledge"}

The Shona also have a cultural approach to identifying water sites for migodhi yemoura (hand-dug wells). Indigenous peoples possess traditional knowledge and skills concerning the identification of a water source site. These include identifying indigenous trees such as mubvumira (kirkia acuminate), muchakata (parinaria curatellifolia), mupanda (lonchocapus capassa) and mushuku (uapaca kirkiana) which are associated with rich sources of groundwater. ${ }^{33}$ Furthermore, these trees are conserved since they have direct impact on the water sources. ${ }^{34}$ Second, churu (termite mounds) are also considered a sign of plenty of groundwater as water is needed for the construction of these mounds. Third, a belt followed by a certain type of chamupupuri (whirlwind) is understood as a table of groundwater. The belief is that a njuzu (a mermaid) is a keeper of water sources in indigenous communities and it travels in whirlwinds. Fourth, indigenous experts in well digging use V-shaped sticks of mutehwa (grewia bicolor) to detect the availability of groundwater. They hold the sticks firm above the ground and availability of water is detected by vibrations of the sticks. The quantity of the water at the place is determined by the strength of the vibrations.

The Shonas' traditional land management skills often provide the most effective method of water resource management in their settlements. For this reason, water sources on indigenous lands are often considered a sacred element, and

32 Ibid.

33 See Maposa and Mhaka, "Indigenous Culture and Water Technology."

34 Mubonani in Chinamasa and Mavhiza, "Participatory Water Sources." 
indigenous people may be the holders of "water knowledge". Kugadzira migodhi yemoura (ritualising the hand-dug deep wells) is a common practice. Ritualised objects like strings or charms that possess mystical, spiritual and therapeutic powers are placed in or at the water source. They act as protective elements which prevent people from contaminating the water or engaging in other unacceptable practices. They also ensure a perennial supply of water.

\section{Case 3: Chikwengweru Pool as a "sourceless source"}

The Chikwengweru Pool is a shallow water source which lies between two granite stones, and is enclosed by wooden. The availability of water is perennial, but water levels decrease if the water spirits are angered. Water from this pool tastes sweet despite the fact that other sources of water in the area have hard, salty water. Water is drawn using utensils that are prescribed especially nonmetal objects like gourds, wooden or clay containers, which have not been used for cooking. It serves more than seventy households in five villages. Those in custodianship of the pool belong to Nemadziva family of the Moyo/Heart totem. The pool is heavily associated with the lightning and thunder that occur each time the area receives rainfall. In terms of quantity the Chikwengweru area receives more rainfall compared to surrounding places. Traditional healers and members of use the water to cure barrenness and other various bodily diseases, to wash away bad luck and to exorcise evil spirits.

The people believe that Chikwengweru pool is a mystery which reveals the work of Mwari. They call it chinyuke/manyuko. According to Gwinyai Muzorewa, an African theologian, though still metaphorical, chinyuke translated as the "sourceless source" or "the source of all sources," means something whose intrinsic existence is bound in and of itself, and serves as the cause of all existence before and yet-to-be. ${ }^{35}$ For the Shona people of Buhera, the "sourceless source of Chikwengweru pool is understood in the context of the unexpected coming of waters in form of a pool in an area which is characterised by aridity. Therefore, in their ecological view, Mwari is believed to be Manyuko, because he is author of "a beginingless and endless" existence. ${ }^{36}$ In everyday life, chinyuke signifies a surfacing of water from underground which all of a sudden emerges to the surface collected in a pool that endures drought.

Villagers in Ward 28 use Chikwengweru water in systematic ways and with deep observance of zviera (taboos) and assorted practices that are grounded in the religio-cultural system. This body of the belief system shapes the locals' interpretation of their perception of the accessibility and utility of the available natural resources. The quality of Shona taboos is that they are restrictive and not directive. Through their cultural belief systems, the Shona people protect this pool from pollution and running dry since it is a habitat of a mermaid. When

35 See Muzorehwa, African origins of monotheism.

36 Ibid. 
approaching the pool, villagers are encouraged not to harbour bad thoughts. Among other things, this helps to control those who might be nursing grudges to the extent of exacting revenge by poisoning water sources. In addition, people are not allowed to hold meetings at the pool. After fetching water people, should leave the place. Those who come to fetch water must desist from using zvimonyodzo (vulgar language). This is a practical way of avoiding conflicts.

People who draw water at Chikwengweru pool use prescribed containers. Villagers are prohibited from drinking water from the pool using open hands or using it to wash their bodies. These practices help to keep the pool purified, by controlling the spread of diseases. ${ }^{37}$ Without these rules, some forms of antisocial behaviour might earn the perpetrator the label of nhundiramatsime, meaning one who urinates in wells of water. ${ }^{38}$ In their beliefs about well-being, the Shona hold that there is a causal connection between the moral condition of the community and its water bodies. ${ }^{39}$

Taboos are an indigenous way of educating and knowing metaphysical issues that are regarded as fundamental to the equilibrium of the social system or to foster order in the society. Reverence to Chikwengweru pool is done as an expression of loyalty to the traditional leaders. Availability of water is only ensured by the ancestors through the role played by traditional leaders, traditional healers, spirit mediums and elders of the community. Ancestral spirits in the area reveal themselves to the indigenous in form of a snake. There is a big, colourful snake about 10 meters long which resides in the pool, and no one is allowed to temper with it. Although the snake is one of the best-known death-dealers in Africa, it is often associated with life-giving water. Presence of the snake is assurance of availability of water which belongs and is given by ancestors.

\section{WOMEN AT THE CENTRE OF TRADITIONAL WATER MANAGEMENT}

Women in traditional African culture fulfil roles that are fundamental to the development of water-centred folklore and associated religious beliefs. ${ }^{40}$ In Buhera, traditional knowledge of indigenous peoples is often passed on via shared practice and storytelling. Women are the custodians of ngano (folklore) used to encourage good water management skills. One such a story is of wild animals in a waterless environment that set out digging a well to survive. All of the animals, including those with great physical strength failed to reach the water table, all except for the despised tortoise. The hare was barred from accessing the well, since it had refused to participate in the digging process. However, the hare used honey to bribe those on guard. After the majority of

37 See Maposa and Mhaka, "Indigenous Culture and Water Technology".

38 Ibid.

39 Taringa N. 2014. Towards an African-Christian Environmental Ethic. Bamberg: University of Bamberg Press.

40 Mukonyora, "Women and Ecology", 280. 
the animals had become victims of the hare's ruse, it was little tortoise's trap which led to the capture of hare and its eventual reprimand. The tortoise had smeared glue upon its body and waited quietly under water waiting for hare's arrival. Later hare came to the well, on its attempt to drink water secretly, and it glued onto the tortoise's body. The tortoise came to be associated with water, and therefore it too is protected by the people.

Through such stories, women use animal imagery to communicate important social values to the young. ${ }^{41}$ The values imparted in youth contribute significantly to the way the Shona, and possibly many other African people with a similar cultural heritage, think about bodies of water and their management. Among other lessons, children learn that aquatic creatures are very important in ensuring the availability of water. There is community ownership of the water sources. Every individual must contribute to the source's management despite his or her age or stature. There exists a body of rules used to govern usage of water sources. Anyone who breaks the agreed laws is reprimanded before being admitted again into the community. Within the Shona indigenous communities, folklore plays an important role, as an instrument of socialisation.

The most popular praise name for Mwari is Dzivaguru, which means the Great Pool. Sometimes the root word Dziva (pool) is used instead of Dzivaguru. ${ }^{42}$ In a Shona ecological system, water is a key fertility feature. A pool of water symbolises the woman's womb as the fountain and origin of life. Dzivaguru is widely associated with feminine aspects of the Mwari belief system. The woman's responsibility is to produce crops for the family; thus, she wants to see the rains fall to replenish the water sources. She is also expected to bear children until nyoka yagume ura. The Shona understanding is that the uterus of a woman consists of a snake that, in its active stages, effectuates reproduction and there comes a time when the snake is no longer active. This is menopause stage. A woman who does not bear children is associated with mhanje - that is an infertile barren land. ${ }^{43}$ Women who are not sexually active also take a central role in rain-making ceremonies in which beer is brewed by mbonga (virgin girls) or vaguma ura (women of advanced age). These women are considered to be Mwari's wives. ${ }^{44}$

41 Mukonyora, "Women and Ecology", 280.

42 Daneel M. 1970. The God of the Matopo Hills. The Hague: Mouton, 16.

43 Ibid.

44 Ibid, 282. Traditionally, rainmaking ceremonies were done at the Matopos cultic centre, where a voice of Mwari was heard communicating with the indigenous people. At this cultic centre there were mbonga (virgin girls) who played a mediatory role between Mwari and the people. The concept "Mwari's wives" is understood as a spiritual union between the mbonga and Mwari, whom they served at this cultic centre. 


\section{WATER, VALUES AND MEANING}

Water sources are imbued with values and take on meaning through people's daily lives and struggles. ${ }^{45}$ There exists a sense of collective responsibility, meaning that each and every member of the community is bound to ensure that he or she fetches water from the water bodies without compromising the ability of present and future generations to meet their water needs in a sustainable manner. It has been noted that water bodies managed from a traditional approach are given a chance to "rest and recover" instead of being over-used. ${ }^{46}$

Despite the rationale for integrating these knowledge systems into modern management practices, indigenous knowledge related to water is still often misunderstood and ignored in water projects, policies and planning processes. Participatory approaches are required in which traditional religion and water education is linked to human experience particularly in rural areas. It is imperative to involve communities in identifying the cultural and social practices that may increase or decrease the water levels in their sources in formulating water policies appropriate for this existential situation.

There is also a need to take into consideration the values, attitude, preferences and capacities of the different stakeholders in the supply and management of water in rural areas. Human practices related to water relations typically date back many generations: hence, in many traditional societies, people have developed cultural values, attitudes and norms of behaviour in relation to water use. ${ }^{47}$

\section{POLICY RECOMMENDATIONS FOR ZIMBABWE WATER MANAGEMENT}

Legal Pluralism: The Shona people's adherence to own water customs and practices suggests that the country should have a legal pluralistic framework that governs water resources. May describes legal pluralism as a situation where the transfer or introduction of one system is superimposed on an existing political structure or culture. ${ }^{48}$ Though legal pluralism is not an easy framework to use in governing natural resources, in practical terms, the rural communities in Zimbabwe are governed by systems that have multiple rules (State, RDC and local) with both legal and customary bases of legitimation and different enforcement structures and processes. ${ }^{49}$ It is important to acknowledge the vitality of indigenous religion in a legal pluralistic framework for it makes use of customary practices for water resources management. Therefore water policy makers should therefore acknowledge and respect indigenous religious water practices.

45 See Rusinga and Maposa, "Traditional Religion and natural resources".

46 Culture and water - Kunene River Awareness Kit. Online at: www.kunene. riverawarenesskit.com

47 Ibid.

48 May in Chikozho and Latham, "Shona customary practices", 1.

49 Nemarundwe in Chikozho and Latham, "Shona customary practices", 7. 
Customary law and practice. Besides for Roman-Dutch law that is reflected in both the common and statutory law of Zimbabwe, there also exist the customary law and practice. The FAO Legislative Study No. 58 provides an in-depth study of the dynamics of customary law in different African ethnic groups. Customary law is a code of rules approved by the indigenous community that has been observed, recognised, and handed down by ancestors since time immemorial. ${ }^{50}$ These laws provide for a set of rights and duties to be observed by the communities. Despite customary law being subjected to pressure from Western religions, colonialism and modernity, its observance is still prevalent in Buhera Shona communities. It is adaptive, which makes it especially resilient as well. Adaptations are iterative, and is found within the shifting landscape of the people's notions of what is culturally acceptable. Culture and customary behaviour are the embodiment of society's legal institutions.

Religious ritual and practice. Closely related to the above, is the fact that the Shona people understand and describe the nature of their Supreme Being in aquatic terms. Their religious world provides tools for identification of water sources and naming and classification of water systems. This rich knowledge source serves as the information base for society, facilitating communication and decision making.

Be that as it may, African indigenous religion dominates the Shona worldview as it does for most Zimbabweans. African well-being is located in its cultural situatedness. Among the Shona, one symbol of their religio-cultural beliefs is water. For this reason, in water-stressed regions, unavailability of water from its sources is understood as a religio-socio-cultural crisis and solutions to these crises are also culturally-oriented. This can contribute to local empowerment, increasing self-sufficiency and credibility of projects and policies. ${ }^{51}$

Water is not only understood as a physical commodity, but also as an inherent religious and cultural value and thus it is associated with the indigenous people's identity. Being understood to be the providers of water, Mawari and the ancestral spirits are contacted when it becomes scarce. This can be done through rain making rituals. These rituals are presided over by traditional religious practitioners who happen to be the living custodians of natural resources including water. The causes of the drying up of water sources are diagnosed through involvement of spirit mediums, and rituals are performed to rectify the problem. Therefore management of water should not be done following legal laws of the government only, for water is a religious substance meant to sustain every human and nonhuman living organism. Through religious observance, there are certain codes of conduct and taboos expected to be followed that serve as a heritage of water resource management as was seen in the aforementioned case studies. Given the prominence of indigenous religious religion in rustic communities, villagers are more comfortable in abiding to a religious water

50 Posselt in Chikozho and Latham, "Shona customary practices".

51 Ibid. 
life management system which they are acquainted to in this way rather those prescribed by water legislation. Also women, who have been seen as close to Mwari in terms of fertility, are noble inculcators of recommended aquatic practices in their families as they educate children in responsible water use via folktales and proverbs.

\section{CONCLUSION}

This study has suggested that management strategies for all water resources include the aim of sustaining and prolonging the life span of water sources in rural areas. Current Zimbabwean water resources legislation does not recognise customary law and practices. As was noted, ZINWA and District Councils are mandated to regulate water systems even in rural communities. In traditional African contexts, such as that of the Shona, natural resource use, management and conservation are products of people's spirituality, culture, practices, taboo systems and knowledge accumulated over centuries. ${ }^{52}$ It should be the prerogative of traditional leaders to deal with water issues in wards and not just that of ward councillors. Yet, customary authorities do not have any formal representation in water regulatory bodies. This is one of the gaps that need to be addressed by adopting legal pluralism in management of water resources.

Findings indicate that traditional religious and cultural practices form the sustainable heritage which contributes towards the conservation of water resources by ascribing psychic powers to the boreholes and pools. Reverence for these water sources has been a pragmatic tool for conflict management. As such, the use of African indigenous laws of water management helps in fostering peace and conflict resolution. Villagers are not allowed to have conflicts lest their water sources will dry up. Peace is a vital resource for social development. Relying on traditional African heritage on water management is easy and affordable since it their way of life, therefore it aids in the social development of people and communities that use it. Besides using it for domestic purposes, water is important in advancing the indigenous people's social wellbeing. Finally, in a sense, the sacredness of water "washes away" minyama (misfortunes) among the indigenous people. Misfortunes or bad luck barricade indigenous people's quest for a successful life. So sources of water become places of renewal or entrance into a new life. ${ }^{53}$

52 Sibanda in Maposa and Mhaka, "Indigenous Culture and Water Technology".

53 Kriel, Roots of African Thought, 3. 